\title{
Foreword
}

\section{Catherine Trautmann}

At times when social and technological changes occur at a pace unseen before, complex social relationships entail the adoption of increasingly convoluted rules for their regulation, often exceeding our capacity to understand all the consequences for human rights.

Today's growing variety of forms of creative expressions, complicated innovation processes, and mechanisms for the remuneration of creators and investors call for a comprehensive normative framework. Often it is not easy to see how specific intellectual property norms interact with provisions of human rights instruments that are usually drafted in broader language. The key issue is how to respect human rights in a constantly changing environment, while fostering creativity and innovation as well as the dissemination of its results through the system of intellectual property rights.

Intuitively, one might say that on many levels there is no link between human rights and intellectual property. The way the two bodies of law developed is interesting. The economic applications of intellectual property on the one hand, and the search for justice through human rights on the other: apparently two rather different worlds which, however, are the subject of a common Article 27 in the Universal Declaration of Human Rights. The first paragraph states that "everyone has the right freely to participate in the cultural life of the community, to enjoy the arts and to share in scientific advancement and its benefits'. It concerns the individual's right to benefit from culture or science while the second paragraph, which emphasises that 'everyone has the right to the protection of the moral and material interests resulting from any scientific, literary or artistic production of which he is the author', bears upon legislators and their capacity to guarantee creators a remuneration for their work. This Declaration highlights that despite an apparent opposition, there is an inherently strong connection between human rights and intellectual property.

Doctrine and history divide human rights into three 'generations': civil and political rights ('fundamental freedoms'); social, economic and cultural rights; and collective rights. One of the issues arising from the application of human rights is whether this classification has any impact when balancing rights in cases of conflict, for example, the right to freedom of expression (or privacy) and the right to property.

Development and wide use of new technologies further complicate interpretation and application of human rights, and hence their interaction with other norms. Does freedom of expression on the Internet constitute a new freedom or is this a new form of expression that should be included in the existing framework? Indeed, in the wake of the expansion of the digital environment, some have called for the creation of specific 'fundamental digital rights'. This idea of an 'Internet Bill of Rights' was at the centre of many discussions in several Internet Governance Forums. But in fact, apart from an abandoned Spanish initiative in 2010 during its Presidency of the Council of the EU, 
which aimed at setting up a 'European Charter of rights of users of electronic communications', there are few comparable projects in the European sphere. Apparently there is a similar initiative in Brazil called Marco Civil da Internet, but, it seems, it is still being discussed by the Brazilian Congress. We, at the European Parliament, have had in parallel the debate about whether access to the Internet is a fundamental right. Many activists and lawyers tend to call for a 'digital review' of pre-existing human rights (and their application in courts). For example, the Dynamic Coalition on the Internet Bill of Rights, which emerged before the 2008 Internet Governance Forum in Rio, established that rather than developing a new set of rules, it would work on guidelines interpreting existing human rights in light of the digital challenges.

Patents are sometimes accused of blocking people's access to medicines, and recent developments in life sciences have also raised some new human dignity-related issues. In October 2005, the European Parliament adopted a resolution on patents for biotechnological inventions which reaffirms that 'the patenting of procedures involving human embryonic stem cells or cells that are grown from human embryonic stem cells is a violation of Article 6(2)' of the 1998 Directive on the legal protection of biotechnological inventions. ${ }^{1}$ This is still the rule today in the negotiations about the new European framework programme for research.

The issue is complex: who is to establish the balance between different rights? With what margin? In the case of copyright, the Court of Justice of the European Union allowed a large margin of appreciation to national legislators. ${ }^{2}$ But would it be the same in the case of industrial property (patents, trademarks)?

In the case of Article 10 (freedom of expression) of the European Convention on Human Rights, the unanimous decision of the European Court of Human Rights in February 2013 to reject the application submitted by the co-founders of The Pirate Bay, gives ground for further reflection on this matter. ${ }^{3}$ The Court admitted that file-sharing, as well as providing a platform or tool for others to share files, was covered by the right to 'receive and impart information', as protected under Article 10. However, the Court also upheld the prior decisions of Swedish courts insisting on the fact that the obligation to protect copyright was a justified limitation of the applicants' right to freedom of expression.

Hence, is there a hierarchy of different rights? In this context, the answer is not black and white.

Proportionality (one of the classical criteria of the European Court of Human Rights 'three-part test') plays a vital role when establishing relations between different rights: in 'The Pirate Bay' case, the Court held that a totally unchecked platform for the exchange of links or torrents was going too far with regard to the protection of copyright. But in another case, involving the Belgian authors' organisation SABAM and the Internet service provider Scarlet, the Court of Justice of the European Union

\footnotetext{
1 Directive 98/44/EC of the European Parliament and the Council of 6 July 1998 on the legal protection of biotechnological inventions, OJ 30 July 1998, L 213/13.

2 ECJ, Case C-275/06, Promusicae [2008], Judgment of the Court (Grand Chamber) of 29 January 2008, ECR I-00271.

3 ECtHR, Neij and Sunde Kolmisoppi v. Sweden (dec.), no. 40397/12, 19 February 2013, unreported.
} 
found that it would be disproportionate to request Scarlet to monitor the traffic going through its network. ${ }^{4}$

In addition, one should recall that every new dossier, be it cloud computing, data protection or the discussion on the Transatlantic Trade and Investment Partnership, gives rise to debates on the bigger picture which inevitably have an impact on the complex relation between human rights and intellectual property.

The search for the right balance between human rights and intellectual property rights in the constantly changing world, in which new phenomena and relations appear quicker than norms are adopted, is where the challenge lies for legislators. There is no doubt that the contributions gathered in this book will be of utmost value for everyone interested in this topic and in particular for legislators at the European, national and international level.

4 CJEU, Case C-70/10, Scarlet Extended [2011], Judgment of the Court (Third Chamber) of 24 November 2011, ECR I-11959. 